\title{
Integrated Vision of Spirituality and Science: A Reflection of Divine Culture on the Earth
}

\author{
Dr. Bir Singh Yadav, \\ Associate Professor, Department of English Central University of Haryana, Jant-Pali, Mahendergarh (India )
}

\begin{abstract}
A rational thinking with an insight into the superior order of things as contained in the divine scheme of this universe leads to an integrated vision of spirituality and science which gives a reflection of divine culture essentially required for the well-being of this world. Philosophy connecting theology and science builds a bridge between spiritual and scientific thinking; and thereby, dissolving the apparently visible differences presents an integrated whole in which a spiritualist becomes a scientist and a scientist becomes a spiritualist. Human mind embellished with spiritual and scientific system of thinking rooted in divine culture reflects ethical values of innate divinity. Rational and empirical priori and posteriori forms of knowledge indeed represent spiritual and scientific thinking process of human mind. Spirituality is a God-particle discovered recently by the science; moreover, scientists approve that scientific musing has its roots in mystical experience which is a direct route to the apprehension of reality and truth. The integrated notion of rational and empirical knowledge is the reflection of divinely designed culture which demands its absorption in human beings on this planet with a sense of eco-justice with the fellow-beings living on the Mother Earth.
\end{abstract}

Keywords: Divine culture, eco-justice, priori and posteriori knowledge, science, spirituality.

\section{Introduction.}

Since the dawn of the humans on this planet, an urge for better, bright and happy future has always been intertwined with the rational thinking of the being which impels to invent better and novel ways of living, consequently rationality reflecting on the nature of life and the world leads to philosophy which is the offshoot of the interface between innate spirituality and the empirical science as Bertrand Russell in the introduction of History of Western Philosophy states that "The conceptions of life and the world which we call 'philosophical' are a product of two factors: one, inherited religious and ethical conceptions; the other , the sort of investigation which may be called 'scientific' using this word in its broadest sense." [1]. Plato takes this world as a translated text in which reality can be observed through translation by adopting the process of decoding and recoding with the help of spiritual and scientific knowledge - the innate and empirical knowledge contained in synthesized form in philosophy as Jacques Derrida asserts that " The origin of philosophy is translation or the thesis of translatability" [2]. Philosophy stands somewhere between theology and science connecting the unascertainable dogmas coming from some authority and the definite knowledge of science, thereby, as Russell further asserts that "between theology and science there is a 'No Man's Land,' exposed to attack from both sides; this No Man's Land is philosophy"-the seasoned and reasoned knowledge of the innate divinity and the empirical science [3]. But the problem in the present scenario is that both science and spirituality are being abused and misused on account of creating a divorce between them whereas an integrated vision of spirituality and science intimately blended in the divine design is the reflection of the divine culture in the world which has been envisioned by the geniuses in all ages and this reflection gives meaning and purpose to life in which lies the essence of living as Albert Einstein states that "The man who regards his own life and that of his fellow creatures as meaningless is not merely unhappy but hardly fit for life." [4]. Therefore, the paper intends to contribute as how to make life meaningful, happy and worth living in this era of advancing techno-science, hence it is essential to take an insight into the divinely designed culture of the universe in the light of innate spirituality and the empirical science as both are the inseparable part of the Divine Knowledge.

\section{Spirituality and Science}

Spirituality and science are inextricably intertwined in their origin as both are the reflection of the divine power in their purest and refined form, hence in the true sense every spiritualist is a great scientist and every scientist is a profound spiritualist as the aim of both is to reflect reality and truth for the welfare of the whole creation on this earth. This truth and reality exists in the mind as well as in nature as Joel Myerson in Transcendentalism: A Reader (2000) points out that " there is divinity within mankind and within nature, and that all divinity is perceivable by each person who lives a life in a way that is in harmony with spirit." [5] Ralph Waldo Emerson propounding his notion of the 'Over Soul' and recognizing the spiritual character of nature also opines that man can know the divine and ultimately become one with it through the keen observation of nature. 
Rising above the time and taking time-continuum into consideration in which man always lives in the "EternalNow' with past as present memory and the future as present anticipation, Emerson in his essay "Self-Reliance" states that 'man can not be happy and strong until he too lives with nature in the present, above time' [6], therefore, the entire progress, be it spiritual or scientific, originated in mind is the outcome of the fruitful intercourse held between the innate divinity of mind and the external world of nature as both of them are two sides of the same Divine Power. Noam Chomsky's belief also highlights innate divinity of mind because his notion is based on the 'innateness', 'intuition' and 'tactical' knowledge in human mind as he assumes that 'the phrase structure rules represent the internalized and unconscious working of the human mind, deep structure determines meaning and surface structure determines sound' [7] which reflects a spiritual and scientific system of thinking in human mind. Nida whose theory of translation is based upon his religious inclination because he perceives everywhere in nature a message to be taken as "Word of God" also points out to the innate structure of human mind and in Message and Mission, engaged in scientific analysis, "breaking new grounds with new tools" [8] he concludes that "ideas must be modified' to fit with the conceptual map of experience [9] also indicates the spiritual and scientific system of thinking in human mind.

Spirituality is filtered divine knowledge far away from superstition and hollow popular religious beliefs whereas science is empirically tested and verified part of the infinite divine whole of knowledge, therefore, integrated vision of spirituality and science in the divine system of the universal whole, as S.T. Coleridge in Biographia Literaria remarks if we have eye to see and ear to hear, is truly a reflection of the divine culture for the bright, better and happy future of mankind on this earth. But unfortunately, what is happening in the presentday world-scenario in different cultures is that spirituality is being abused and misused in the name of false religion whereas science is passing through stifling tunnel of narrowness by making itself more specialized turning its back on humane thoughts. Einstein rightly thinks that if religions are not "purified of the elements of superstition" and science is not replete with spiritual and ethical values, "there is no salvation for humanity" [10] because without ethical culture all these hard-won achievements of science in the hands of our generation are like "a razor wielded by a child of three" [11], therefore, the need of the hour is that we must connect science with spirituality as Einstein remarks that "We must build spiritual and scientific bridges linking the nations of the world" [12]. In order to understand the intimate co-existence of spirituality and science we will have to go to their roots to make a sound and solid bridge for happiness in the existing most civilized world of today.

III. Nature of Reality.

Both spirituality and science are moving towards the realization of the nature of reality in their own ways for the fair and better understanding of the world, hence at the very outset, a step towards knowing the nature of reality is a must as both of them are oriented towards its revelation. Generally speaking reality means the quality of being real or that which underlies the appearances, or it is the truth hidden under appearances or phenomena; or it may be taken as true or actual nature of something. The philosophic school of idealism regards reality as "spiritual or mental" and atomism takes it as "plenum" whereas realism regards it as the objective existence of a subjective conception and states that "in human knowledge objects are grasped and seen as they really are in their existence out side and independently of the mind" [13]. Plato takes 'forms' and 'ideas' as reality which are different from appearances or phenomenal manifestations and according to him reality has an underlying, timeless and unchanging nature. [14]. Aristotle rejecting Plato's dualism sees reality as a "composite substance of matter and form' [15]. Naturalism believes that "the only reality is nature" and change is "an essential and inescapable part of reality" [16]. Materialism takes matter as reality but rationalism regards that reality has an inherently logical structure as Hegel asserts that "the real is rational, and the rational is real" and truth is the whole [17]. Descartes takes God, mind and matter as reality whereas for Spinoza both thought (mind) and extension (matter) are the attributes of the same supreme reality-the Divine Being. Leibniz does not accept matter as reality and holds the view that 'reality is constituted by the pre-established harmony of monads' [18] whereas empiricists like David Hume think that the ultimate constituents of things are not 'material but mental' and Berkeley also emphasizes that all reality is mental. William James, the pragmatist, asserts that reality is 'neutral monism' and "a true idea must agree with reality" [19] but the Eastern philosophers like Sri Aurobindo, Swami Vivekananda, R.N. Tagore and S. Radhakrishnan espouse the spiritual nature of reality. According to Buddha reality "whether of external things or the psycho-physical totality of human individuals consists in a succession and concatenation of microseconds called dhamma" [20]. In the light of all the afore mentioned views it is clear that reality and truth can be apprehended with rational and empirical approach, therefore, an integrated vision of spirituality and science reflecting divine culture becomes essential for the peaceful coexistence and fair understanding of the nature of life in this world .

4.1. Spirituality and Science in Literature. William Wordsworth reflects the integrated spiritual and scientific system of the divine culture by taking duty as the divine postulate of the universe as well as a divine spark within the soul. With an inspired insight he sees duty and creativity moving hand in hand everywhere in the 
universe maintaining its decorum and beauty with dynamism and recreation. Penetrating into the superior order of the things with an inner eye Wordsworth highlights the divine power of duty in the garb of spiritual and scientific system of this universe reflecting the culture of perfect co-operation and co-ordination that can bring happiness in the world as in the poem "Ode to Duty" he articulates:

Flowers laugh before thee on their beds

And fragrance in thy footing treads;

Thou dost preserve the stars from wrong;

And the most ancient heavens, through Thee,

Are fresh and strong. [21]

Wordsworth presents the reflection of the divine culture by envisioning how the dutiful, coordinated and cooperative system among the natural elements and objects in this universe does create wonders in the world. The sun gives heat as a result of which the air becomes hot and rises up, fresh air passes over the oceans and taking water vapors forms the clouds in the sky, water is taken to such a height without any container and it falls back on the earth in the form of tiny rain-drops, resultantly the mother earth becomes happy with greenery, plants grow and blooming flowers spread their sweet fragrance everywhere., it is the blessing of duty-culture inherent in the natural objects. This divine culture of duty is perceptible everywhere in this universe and it keeps all the heavenly bodies in their respective orbits as it does not let them to go astray from their respective right path. This divine power of duty infuses such an inexhaustible energy in the most ancient heavens that they remain fresh and strong for ever. In a very scientific way Wordsworth conveys this divine message to all human beings that the secret of peace, prosperity and happiness of this world lies in the sincere performance of one's respective duty with a sense of perfect coordination and cooperation; and the pragmatic application of this spiritualized scientific vision of idealism can make a paradise of this world. Therefore, we must learn a lesson from the divine culture of dutifulness which is being reflected through the duty-imbibed natural objects. Wordsworth with the growth of the philosophic mind embellished with the divine culture of duty in its holistic perspective crossing the physical boundaries of the mortal life as well as the physical world makes realization of the spiritual culture in the most scientific way in the light of the divine message of duty coming from the core part of the human soul which inspires us to go ahead with scientific thinking in the light of spirituality that will never betray and will not allow us to deviate from the right path in the eternal journey of life.

Sincere and judicious performance of duty preserving its divine sanctity becomes a panacea for all the ills of the modern world. Brushing aside all the weaknesses and temptations dragging us to dross of sinfulness and corruption prevailing everywhere in the contemporary world, it is the divine culture of duty by inculcating in us the spirit of self sacrifice and confidence of reason based on the foundation of righteousness in the light of truth can save this world from the political, social, economic, cultural, moral and religious maladies which are posing serious threats to the existence of this planet. If every person at one's assigned station as related to the nature of duty from the lowest to the highest level-from the poor laborer; or from the peasant to the crown becomes the worshipper of duty in place of false religion which brings countless sins within its ambit, most of the problems of this multicultural, multiethnic, and technocratic global world can be solved. 'The spirit of selfsacrifice' and 'confidence of reason' in 'the light of truth' correlate the two poles of spiritual and scientific thinking which should be taken as inherent ingredients in the integrated whole of duty. This divine culture of duty saves us from the gross materialism of this world and provides solace and satisfaction to human soul as Shakespeare in The Merchant of Venice articulates through Portia, who has performed her duty well by imparting justice in the light of divine culture with the openness of the text of law that:

He is well paid that is well satisfied;

And I, in delivering you, am satisfied,

And therein do account myself well paid:

My mind was never yet more mercenary [22]

The Gita also imparts the message of duty with sublime feeling of non-attachment as Lord Krishna preaches Arjuna that "karamanya evadhikarste ma phalesu cadachan / ma karama-phala-heturbhuir ma te sango sta akarmani" [23] -You have a right to perform your prescribed duty, but you are not entitled to the fruits of action. Never consider yourself the cause of the result of your activities, and never be attached to not doing your duty. Duty with its divine character also saves us from fanaticism, impulsiveness and selfishness as it has rational, scientific and spiritual nature that glorifies human life not only in this world but also prepares a bright future for the spiritual self with inherent divine light moving cheerfully towards the ultimate divine power through perfection and emancipation. William Lillie takes duty as "the moral authority inside the individual; it is an inner voice that directs him" and further states that "it is the voice of God speaking in the soul of man" [24], thereby the duteous persons contribute to the creation of knowledge and new values as their creativity assumes divine form in the garb of duty, hence it is duty that inspires us to proceed from egoism to altruism which should be the ultimate goal of human life. Tagore also regards duty as true religion or a real spiritual feeling; exposing all kinds of ostentation in religions and glorifying a duteous common dust stained face in Gitanjali he sings: 
Leave this chanting and singing and telling of beads.

Whom dost thou worship in this lonely dark corner of a temple with doors all shut.

Open thine eyes and see thy God is not before thee.

$\mathrm{He}$ is there where the tiller is tilling the hard ground And where the path maker is breaking stones.

He is with them in sun and shower, and his garment is covered with dust.

Put off thy holy mantle and even like him come down on the dusty soil.[25]

In 'False Religion' he states that the boat of false religion which is full of sinful holes is sure to sink whereas the fanatics think that they will get salvation by killing the people of another faith. He prays to God to destroy the temple of this false religion (ignorance and superstition) with his thunder- stroke because blood shedding in the name of religion does not find any place in spirituality, hence the need is to save spirituality from the sinful drops of false religion by analyzing it in scientific thinking. Moreover, religion is personality respecting force not personality insulting as he gives vent to this feeling in his One Act Play "Chandalika" through Prakriti who confidently asserts that "A religion that insults is a false religion"[26]. Thus Tagore respects spirituality but rejects the obsessive notion of false religion as he demands that religion should be analyzed in the light of scientific thinking with perfect objectivity so that it can get rightful and respectful place in divine culture.

If spiritual values are not replete with scientific thinking the day is not far away when a great danger will threat the peaceful co-existence of the so-called civilized and advanced modern world and the picture in the absence of spiritual and moral values will be as Matthew Arnold depicts in the concluding lines of the poem " Dover Beach" : Ah love, let us be true,

To one another! For the world, which seems

To lie, before us like a land of dreams,

So various, so beautiful, so new

Hath really neither joy, nor light

Nor certitude, nor peace, nor help for pain:

And we are here as on a darkling plain

Swept with confused alarms of struggle and flight,

Where ignorant armies clash by night. [27]

P. B. Shelley in his poem "Ode to the West Wind" with a peculiar insight recognizes this spiritual power of the universe engaged in a scientific way in the act of 'creative destruction' as he gives a call to it by articulating "Wild Spirit, which art moving everywhere; / Destroyer and preserver; hear, o, hear!" [28]. This sublime concept of creative destruction for the establishment of new values in the society with a total change has been conveyed in a beautiful way where spirituality and science in incarnated form descends on the earth whose secret the Lord tells Arjuna in The Gita " yada yada hi dharmasaya galanir bhavanti bharata / abhyautthanam adharmaysa tadatamatanam sarjayam aham" [29]-Whenever and wherever there is decline in religion , $\mathrm{O}$ descendent of Bharata, and a predominant rise of irreligion - at that time I descend myself. It is the integrated vision of spirituality and science that cleanses the society from corruption, injustice and irreligion. John Keats in Hyperion also points out to the same creative spiritual power by which old values are replaced by the new ones and in the broader aesthetic frame of value system his visionary mind perceives it as 'Beauty' which is "Truth ' in itself as he concludes in the poem "Ode On a Grecian Urn" that "Beauty is truth; truth beauty - that is all, / Ye know on earth, and all ye need to know." [30] It is 'Beauty' ,as Hegel also opines, that beauty starts from the common things of this world, and by and by goes on mounting up to the highest form of beauty where it assumes the form of the ultimate truth, the spiritual power of this universe. Hence realization and cultivation of this power of beauty in man is the spark of the divinity, therefore, appreciation and creation of beauty in any form is also a reflection of the divine culture on this earth that needs to be absorbed in our character. Lord Byron recognizes this spiritual power working against the tyranny and despotic authority as in the poem 'The Ocean" which is an extract from the concluding part of Child Harold's Pilgrimage he addresses this power as 'glorious mirror, where the Almighty's form / Glasses itself in tempests; in all time,"-- and "The image of eternity, the throne / Of the Invisible;' [31] William Blake drifting away from anthropocentrism and moving towards a higher level of justice in the bio-centric world with pan-humanistic insight takes spirituality as justice giving power to non-human world as he realizes their pains and sufferings with a more sympathetic heart as he depicts it in the poem "Auguries of Innocence" by articulating that "A Robin Red breast in a Cage / Puts all Heaven in a Rage" [32]. All these visionary with their divine power of imagination are the advocates of the divine culture, hence they move their arguments forward in their own different ways in favor of eco-justice, the spiritual principle of this universe. Shakespeare also sees this god-like divine essence in man that raises him above the rest of the creation as he gives clue to it in Hamlet by articulating :

What is a man;

If his chief good and market of his time

Be but to sleep and feed? A beast, no more,

Sure, he that made us with such large discourse, 
Looking before and after, gave us not

That capacity and godlike reason

To rust in us unused. [33]

John Milton also gives inkling to the loss of this divine culture based on right reasoning rooted in spirituality and science as in Paradise Lost expressing his deep concern over the loss of true liberty he articulates that 'Since thy original lapse, true Liberty / Is lost which always with right Reason dwells"[34]. Alfred Lord Tennyson expresses his faith in the Divine and unseen spiritual power of this universe that always guides us reflecting on our innate divinity as in the poem "Crossing the Bar" expressing his faith in God and immortality of soul he comes forth with his spiritual musing:

For tho' from out our bourne of Time and Place

The flood may bear me far,

I hope to see my pilot face to face

When I have crost the bar. [35]

An echo of this spiritual eternal journey is also audible in Henry Vaughan's poem "The Retreat" when he sings:

Some men a forward motion love

But I by backward steps would move;

And when this dust falls to the urn,

In that state I came, return. [36]

Walt Whitman also speaks in the same tone of spirituality expressing his faith in the spiritual essence and its eternal journey when in "Song of Myself" he pours out that "There is that is in me-I do not know what it is - but I know it is in me" and further he says "Missing me one place search another,/ I stop somewhere waiting for you." [37] Robert Browning giving inkling to this eternal journey in the poem "A Grammarian's Funeral' asserts that "What's time? Leave Now for dogs and apes:/ Man has forever." [38] All these concepts are in conformity with the energy concept of science that the flow of energy goes on eternally changing its forms and same is the case with our spiritual essence.

4.2. Scriptures. The Gita also substantiates the point of spiritual energy in the form of the immortality of the soul as Lord Krishna in his sermon to Arjuna says:

Vasamsi jirnani yatha vihaya navani grahnati naro parani

Tatha sarirani vihaya jirnanyanyani samyati navani dehi [39]

(As a person puts on new garments, giving up old ones, the soul similarly accepts new material bodies, giving up the old and useless ones). Change of body by the atomic individual soul is a fact and though the modern science does not believe in the existence of soul, yet it has to accept the continuous change taking place in body from the childhood to boyhood, from boyhood to youth, from youth to old age, and from old age to a new body which is beyond the empirical nature of science. The mechanical system of science exhibiting bodily changes and the spiritual system through which life is renewed or transferred to another body show how the physical world of science and the spiritual world of divinity through their proper coordination and cooperation are making the life and the world move towards the realization of higher values. The empirical nature of medical science analyses the functioning and construction of the body-system (matter) and it has got success in transplanting different parts of body including heart whereas the spirituality reflects the immortal nature of the spiritual self which is beyond decay and destruction as Lord Krishna utters:

Nainam chindanti sastrani nainam dahati pavakah /

$\mathrm{Na}$ chainam kledayanty apo na sosayati marutah" [40]

(The soul can never be cut to pieces by any weapon, nor burnt by fire, nor moistened by water, nor withered by wind)

In the Katha Upanishad surprisingly we find it in scientific system of thought:

Sarvanayapi bahubhir yon a labhyah

Sarnvanto 'pi bahavo yam na vidyuh

Ascaryo vakta kusalo 'sya labdha

Ascaryo 'sya jnatta kusalamusistah [41]

(The atomic soul is within every body but man with a poor fund of knowledge can not understand the wonders of this atomic spark. It is very difficult to find a person who can perfectly understand the position of the Supersoul, the atomic soul, it is a God -particle that science has recently discovered)

As the moon receives light from the sun for illumination, similarly soul gets energy from the Supreme Soul-God. The relationship between the two is eternal and harmonious, hence it is spiritually presumed that God is always with man in the world and man should try to observe His reflection everywhere and in every object of the world such kind of thinking will lend him help in the inculcation of the divine culture. Both the Mundaka Upanisad (3.1.2) and the Svetasvatra Upanisad (4.7) also give confirmation to this point by stating that "Although the two birds are in the same tree, the eating bird is fully engrossed with anxiety and moroseness as the enjoyer of the fruits of the tree. But if in some way or other he turns his face to his friend the Lord and 
knows His glories - at once the suffering bird becomes free from all anxieties" [42]. This bedrock of Vedanta has also been highlighted by A. K. Ramanujan in his poem titled "Questions" in the volume Second Sight taken from the Mundaka Upanisad:

Two birds on the self same tree:

One of them eats the fruits of the tree'

The other watches without eating. [43]

The living body is also a mini-universe functioning according to the laws as discovered by medical science with the existence of the spiritual essence. Moreover, The Atharvaveda describes it as a moving chariot stating-'Ramante yashmine sah rathah' (also in The Gita, 6:34). The spiritual self or soul is a passenger in the chariot of the material body which is made of bones covered with skin- curtains, being driven by the powerful sense-horses and these horses are being controlled by the mind who is holding the rein of manna tightly, otherwise, these horses will drag it to some ditch or hell. Therefore, we must consider the constitution of this living body or life in the light of the integrated vision of spirituality and science which is the reflection of the divine culture.

\section{Mysticism and Science.}

Scientists also approve the point that spiritual knowledge is gained through mysticism as Paul Davies remarks that mysticism is " a direct and immediate route to knowledge that bypasses reasons." [44]and similarly Rudy Rucker in Infinity and The Mind asserts that mysticism is a direct way to truth as mystical knowledge is attained all at once" [45]. Ken Wilber in Quantum Questions also shows that in a mystical experience "Reality is apprehended directly and immediately." [46]. Eminent scientists like Brian Josephson and David Bohm also approve the mature form of mysticism as they think that knowledge gained by "quiet meditative practices" proves useful even in the formulation of scientific theories" [47]. From the epistemological point of view, empiricist John Locke thinks that mind is "white paper, void of all character, without any ideas" at the time of our birth; and from experiences "all our knowledge is funded" [48] but facts are found contrary to it as every individual sees and interpret objects and the world differently which proves empiricism a partial view of knowledge and the German philosopher Immanuel Kant countering it asserts that the function of the mind is not only to arrange material given in sense awareness but it does add its own order and structures into sense experience which proves the existence of priori knowledge in the form of innate ideas that gives confirmation of the spiritual essence. Locke when expresses his faith in intuitive knowledge is also seen close to the point as he believes that the truth which the mind perceives at the first sight "is the most clearest and the most certain" [49] Rationalism advocates its strong claim by stressing that mind imposes its own inherent categories or form upon incipient experiences. Martin Heidegger in the Being and Time also proves the existence of a priori knowledge as he explains that the world is not established by proof but the world is something already given in the structure of human consciousness. Spinoza and Leibniz are also of the opinion that the framework of the things can be comprehended by a priori knowledge. Reiterating it Wordsworth's articulation in the poem "Immortality Ode' also gives inkling to it:

Our birth is but a sleep and a forgetting;

The Soul that rise with us, our life's Star,

Hath had elsewhere its setting,

And cometh from afar

Not in entire forgetfulness,

And not in utter nakedness,

But trailing clouds of glory do we come

From God who is our home. [50]

\section{A priori Knowledge.}

This spiritual knowledge of the eternal relevance is always with the soul in the form of innate ideas which is recognized by the science as genetically advancing knowledge. These axioms in the mind are the evidence of a priori knowledge of spiritual character as Plato opines that they are learnt by the soul before birth in the previous life and substantiating the point Leibniz asserts that these are some ideas and some principles which don't come to us from the senses but we find them in ourselves without forming them although the senses give us occasion to perceive them. and they get confirmation in empirical way. Irish philosopher John Berkeley is also of the opinion that the knowledge of the external world perceived by the senses is interpreted by rationality which is the spiritual quality of the mind. From the biological standpoint, mind is an emergent in the biological evolution. The French Bergson and the American Dewy, advocates of the instrumental theory of mind with an impact of Darwinism also hold that "mind has emerged in the course of biological evolution as an instrument of man's adaptation to the environment" [51]. Hegel, Bradley and Royce are also of the opinion that every true idea has consistency with innate rationality and the nature of the 'whole of the reality.' All the aforesaid views strengthen the integrated notion of rational and empirical knowledge which logically takes us 
to the integrated vision of spirituality and science reflecting ultimately the system of divine culture that needs to be inculcated in us .

\section{Freedom and Creativity.}

Undoubtedly science has contributed a lot to social, political, economic, cultural and technological development as it has blessed us with god-like powers but if these powers are not saturated with spirituality the world in spite of moving towards emancipation may lead to annihilation. Chetan Bhagat, an icon of the postmodern youth, expressing his concern over the loss of spiritual and ethical values in the technical system of education, which is creating hum-drum existence, confesses in Five Point Someone that the IITians, who are expected to conquer the world, are struggling to survive and ultimately are going to lose it and in Revolution 2020 , he anticipates that the prevailing corruption and misuse of power in the technologically advancing world of today in the absence of spiritual and moral values is not an auspicious indication of genuine progress for the coming generation on this planet. In this postmodern era when life has become more comfortable in almost all walks of life with the blessings of science and we want to enjoy full freedom but we must keep it in mind that without spiritual and ethical values this freedom may prove dangerous as John Macquerrie in Existentialism points out that freedom " seems to contain in itself the seed of its own destruction, so the mystery of the origin of freedom runs together with the mystery of the origin of evil" and further states that "Freedom may be dangerous, but there is no human dignity without freedom" [52]. Therefore, Scientific development, genuine freedom and creativity coupled with spirituality reflect the color of the divine culture which is conducive to real peace, progress and prosperity of this world. Thus man endowed with freedom and creativity; and exercising them with the power of science replete with spirituality, can contribute to the divine scheme by creating new values which can alter and improve the conditions of the God-created world and thereby can move towards ecojustice which is the need of the hour for the integrated whole of spirituality and science.

\section{VII.Conclusion.}

The integrated vision of spirituality and science is the only helping hand to us for the solution of the cultural, ethnic, racial and gender problems which the modern global world is facing at present. It also reflects the real nature of Eurocentric, Anthropocentric and Androcentric world which in the light of scientific and spiritual thinking demands justice. Man, being a paramount being and an integral part of this spiritual universe, is expected to establish harmonious relationship not only with the fellow-beings-both humans and nonhumans but at the apex level it is his moral responsibility to maintain harmonious relationship with the rhythms of the universe by providing proper space to the world of nature including birds, beasts and trees which will be the reflection of his divine culture conducive to happiness. The wrong notion that man has adopted is 'entitlement' in relation to the earth than 'belongingness', consequently he thinks that he is the virtual owner of this earth and has the right to exploit other beings and natural resources for his selfishness and these perceptions as Graham Huggan and Helen Tiffin in Postcolonial Ecocriticism (2010) think "have always been more inclined to be narrowly anthropocentric than broadly eco-centric" [53] and resultantly as Jonathan Bate suggests that on the earth "dwell with" is being substituted by "build upon" [54] which is contrary to the spiritual and scientific thinking of the divine culture. Man's commitment to spiritual and scientific thinking will assign him his graceful position as a human being as Jean Paul Sartre in his essay "Existentialism is Humanism" rightly asserts that "we define man only in relation to his commitments" and further stressing creativity emphatically states that "Man makes himself; he is not found ready made" [55] . Therefore, man is himself responsible for his making or unmaking because through his actions he infuses meaning and purpose in life as Sartre further suggests that "Life is nothing until it is lived; but it is yours to make sense of, and the value of it is nothing else but the sense you choose"[56], hence what life is depends on thinking and doings; and if thinking and doings are in the light of science and spirituality, life gets a halo of admiration and illumination scattering around the light of happiness, hence endowed with freedom and creativity man becomes what The Pope in The Acting Person calls "a potential being" [57] . In this way man provides a shape to his destiny and the world with his divine innate creative power and takes him out of the iron-cage of fatalism which is harmful to his progress, consequently the notion that man's destiny is prefixed and human efforts can not change it proves superstitious in the light of spiritual and scientific thinking. The rational nature of the world as well as of the human beings give clear indication that the scientific world of thought has strong spiritual foundation which may not be verified empirically but it does exist as Einstein connecting science to spirituality and placing spirituality on a higher level asserts that "the rationality or intelligibility of the world lies behind all scientific works of a higher order" and this notion which Spinoza calls 'pantheistic' belief Einstein says "represents my conception of God" [59]. Strengthening the bond between spirituality and science as well as reflecting their integrated vision Einstein asserts that "I can not conceive of genuine scientist without that profound faith. The situation may be expressed by an image: science without religion is lame, religion without science is blind" [60]. Thus, this integrated vision of spirituality and science is the reflection of divine culture whose absorption in human nature may prove conducive to peace, prosperity and progress of the world. 


\section{References:}

[1] Bertrand Russell, History of Western Philosophy (London and New York :Routledge2004). (1)

[2] Jacques Derrida, The Ear of the Other: Text and discussion with Jacques Derrida.Ed. Christie McDonald, trans. Peggy Kemuf (London: university of Nebrasaka Press, 1985). (120)

[3] Bertrand Russell, History of Western Philosophy (London and New York :Routledge2004). (1)

[4] Albert Einstein, Ideas and Opinion (Cambridge, 1982). (4)

[5] Joel Myerson, Transcendentalism: A Reader (Oxford: Oxford University Press, 2000). (xxviii)

[6] Ralph Waldo Emerson, Emerson's Prose and Poetry. Ed Joel Porte and Saundra Morris (New York: W.W. Norton \& Company, 2001). (129)

[7] Noam Chomsky, Aspects of the Theory of Syntax.( Cambridge: M.A. The MIT Press,1965). (22)

[8] Eugene A. Nida, Message and Mission. The Communication of Christian Faith ( New York: Harper and Brothers, 1985). (XVII)

[9] Ibid. (87)

[10] Albert Einstein, Ideas and Opinion (Cambridge, 1982). (54)

[11] Ibid. 98 .

[12] Ibid. 149

[13] The New Encyclopedia Britannica ed..Philip. W. Goetz (Chicago: Encyclopedia Britannica Inc.,1988) . ( 25: 626, 584, 626).

[14] G.T. White Patrick, Introduction to Philosophy (New Delhi: Surjeet Publication, 1978). (213)

[15] Will Durant, The Story of Philosophy ( New York, London: O.U.P.,1961). (69-72)

[16] Charles Landesman, Philosophy: An Introduction to the Central Issues.( New York, 1984). (198-199)

[17] Bertrand Russell, History of Western Philosophy (London and New York :Routledge 2004). (702)

[18] Ibid. (553-54)

[19] Ibid. (771)

[20] The New Encyclopedia Britannica ed..Philip. W. Goetz (Chicago: Encyclopedia Britannica Inc.,1988).(25: 274).

[21] William Wordsworth, "Ode to Duty", The Complete Works of William Wordsworth (London; Wordsworth Poetry Library, 2006). (45-48)

[22] William Shakespeare, The Merchant of Venice. Shakespeare Complete Works. Ed. W. J. Craig (Bombay, Madras: O.U.P. 1983). (Act IV, Sc. I; 413-416)

[23] The Gita. Ed, (trans.). Shri Madhusudhan Saraswati.( Varanshi: Chowkhamba Sanskrit Series, 1962). (2:47)

[24] William Lillie, An Introduction to Ethics (New Delhi: Surjeet Publication 1991). (61,76)

[25] R.N. Tagore, Gitanjali (New Delhi: Rupa \& Co., 2002.). ( Song, XI)

[26] Chandalika. Snapshot. Ed. S.K. Sharma.( O.U.P.,2005). (80)

[27] Matthew Arnold. "Dover Beach" Poetry of Matthew Arnold (London: Oxford University Press, 1997).29-36.

[28] P. B. Shelley, "Ode to the West Wind", The Selected Poetry and Prose of Shelley (London: Wordsworth Poetry Library, 2002). (1314)

[29] The Gita. Ed, (trans.). Shri Madhusudhan Saraswati.( Varanshi: Chowkhamba Sanskrit Series,1962). (4:7)

[30] John Keats, Hyperion. "Ode on a Grecian Urn." The Complete Poems of John Keats. Ed. Paul Wright (London: Wordsworth Poetry Library, 2001). (49-50)

[31] Lord Byron, "The Ocean". Child Harold's Pilgrimage. The Works of Lord Byron. Poetry. Ed. Ernest Hartley Coleridge (London:O.U.P. 1903). (37-38,42-43)

[32] William Blake, "Auguries of Innocence”. Poetry and Prose. (London: O.U.P.,1984). (180)

[33] William Shakespeare, Hamlet. Shakespeare Complete Works. Ed. W. J. Craig (Bombay, Madras: O.U.P. 1983). (Act IV,Sc.IV:3339)

[34] John Milton, Paradise Lost (New Delhi: UBS Publishers, 2ooo). (Book XII, 83-84)

[35] Alfred Lord Tennyson, "Crossing the Bar". Chronicles of Time. Ed. Asha Kadyan (OUP, 2004). (13-16)

[36] Henry Vaughan, "The Retreat". Chronicles of Time. Ed. Asha Kadyan (OUP, 2004). (29-32)

[37] Walt Whitman, "Song of Myself". Leaves of the Grass (London: OUP, 1986) (50, 52)

[38] Robert Browning, "A Grammarian's Funeral” The Poems of Robert Browning. Ed. Tim Cook. (London: Wordsworth Poetry Library, 1994). (83-84)

[39] The Gita. Ed, (trans.). Shri Madhusudhan Saraswati. (Varanshi: Chowkhamba Sanskrit Series, 1962). (1:22)

[40] Ibid. (1:23)

[41] Swami Prabhupada, Bhagavada-gita As It Is (Mumbai: the Bhagativedanta Book Trust,2010). (1.2.7: 103)

[42] Ibid. (95-96)

[43] Ramanujan, A. K. "Question", Second Sight.( New Delhi: Penguin, 1994). (3.1.2)

[44] Davies, Paul. The Mind of God.( Harmondsworth: Penguin, 1983). (24-25)

[45] Rudy Rucker, Infinity and the Mind (Boston: Birkhausr, 1982). (170)

[46] Ken Wilber, ed. Quantum Questions (London: New Science Library, 1984). (7)

[47] Paul Davies, The Mind of God. Op. cit. (227)

[48] John Locke,An Essay Concerning Human Understanding (London : O.U.P. 1992) (.i. 2)

[49] Ibid. ( IV.1:2)

[50] William Wordsworth, "Immortality Ode", The Complete Works of William Wordsworth (London; Wordsworth Poetry Library, 2006). (Stanza-V)

[51] The New Encyclopedia Britannica . ed..Philip. W. Goetz (Chicago: Encyclopedia Britannica Inc.,1988). (25:766:1b).

[52] John Macquerrie, "Existentialism is Humanism." Existentialism.( Harmondsworth: Penguin.1987). (180)

[53] Graham, Huggan and Helen Tiffin . Postcolonial Ecocriticism (London: Routledge, 2010). (84)

[54] Jonathan Bates, The Song of the Earth(. London: Picador, 2000). (266, 282)

[55] Jean Paul Sartre, "Existentialism is Humanism" Existentialism from Dostoevsky to Sartre. Ed. and trans. Walter Kaufmannn (New York: Meridian, 1956). (306)

[56] Ibid. (309)

[57] Cardinal Karol Wojtla, (Pope John Paul II). The Acting Person. Trans. Potochi Dordrechet (Boston, London: D. Raidel Publishing .Co., 1979). (153)

[58] Albert Einstein, Ideas and Opinion (London :Cambridge, 1982). (262)

[59] Ibid.(262)

[60] Ibid. (46) 